\title{
SEDIMENTOLOGICAL PARAMETERS AND DATING OF POST- BARREIRAS SEDIMENTS FROM REGION THE COASTLINE
}

\author{
parâmetros sedimentológicos e datação de sedimentos pós-barreiras da região costeira
}

\author{
Cristiano Marcelo Pereira de Souza * \\ Liovando Marciano da Costa ** \\ Ana Maria Souza dos Santos Moreau *** \\ Ronaldo Lima Gomes ****
}

\begin{abstract}
Resumo
Embora haja alguns trabalhos a partir da década de 80, pouco se sabe sobre a origem e mecanismos de depósitos destes sedimentos. O objetivo deste estudo foi analisar os parâmetros sedimentológicos, morfologia granulométrica e datação dos sedimentos. Foram coletadas amostras de Pós-Barreiras e sedimentos de praia,

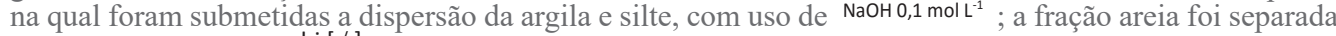
em intervalos de $1 / 2$ phi $[\phi]$. Foi analisado a morfologia dos grãos via microscópio ótico. Empregou-se a datação em amostras pelo método de Luminescência Opticamente Estimulada. Os resultados indicam que os sedimentos Pós-Barreiras foram depositados em ambiente de elevada energia, presumivelmente pela contribuição maior de processos marinhos com possíveis retrabalhamentos eólicos. Os sedimentos de praia frontal apresentaram características de deposição eólica. As datações definiram que a deposição dos sedimentos Pós-Barreiras foi do Pleistoceno tardio até o Holoceno (de 6.9 a 85.4 ap). A posição altitudinal dos sedimentos Pós-Barreiras (40 a 150 m), não pode ser associada a qualquer nível de elevação mar conhecida, o que surge a hipótese de processos de neotectônicos promovendo a elevação.
\end{abstract}

Palavras chave: Tabuleiros costeiros; Datação; Quaternário; Sedimentos arenosos.

\begin{abstract}
Although there is some work from the $80 \mathrm{~s}$, little is known about the origin and mechanisms of these sediment deposits Post-Barreiras. The aim of this work was to analyze the sedimentological parameters, particle size and morphology of grains of sand and dating of sedments. samples Post-Barreiras and beach sediments were collected, which were subjected to dispersion of clay and silt, using $\mathrm{NaOH} \mathrm{0,1} \mathrm{mol} \mathrm{L}^{-1}$; the sand fraction was separated at intervals of $1 / 2$ phi $[\phi]$. The morphology of the grain was analyzed through optical microscope. We used the dating of three samples by the method of Optically Stimulated Luminescence. Results indicate that the Post-Barreiras sediments they were deposited at high energy environment, presumably by a higher contribution of marine processes with possible aeolian reworkings. Beach front sediments showed characteristics of aeolian deposition. The dates determined that the deposition of Post-Barreiras sediments was from the late Pleistocene to Holocene epoch (from 6,950 to 85,350ka). The altitudinal position of Post-Barreiras sediments $(40-150 \mathrm{~m})$ cannot be associated to any known sea elevation level, which then emerges the hypothesis of neotectonic processes promoting elevation.
\end{abstract}

Key words: Coastal tablelands; Dating; Quaternary; Sandy sediments.

\begin{abstract}
Resumen
Aunque hay algunas obras de los años 80, poco se sabe sobre el origen y los mecanismos de los depósitos de sedimentos la formación Barreiras. El objetivo del presente trabajo fue analizar los parámetros sedimentológico, morfología de los granos y la datación de sedimentos. Se recogieron muestras de sedimentos Pós-Barreiras y sedimentos de la playa, en el que se sometieron a la dispersión de arcilla y limo, utilizando $\mathrm{NaOH} 0,1 \mathrm{~mol} \mathrm{~L}^{-1}$; la fracción de arena se separó a intervalos de $1 / 2$ phi $[\phi]$ y la morfología del grano se analizó por medio de microscopio óptico. Utilizó la datación de muestras por el método de luminiscencia ópticamente estimulada. Los resultados indican que los sedimentos Pós-Barreiras fueron depositados en ambiente de alta energía, presumiblemente por el aumento de la contribución de los procesos marinos con posible reelaboración viento. Los sedimentos de la playa delanteros mostraron características eólicas. Las edades determinaron que la deposición de los sedimentos Pós-Barreiras fue a finales del Pleistoceno al Holoceno (de 6.9 a el $85,4 \mathrm{ka}$ ). La posición latitudinal de los sedimentos Pós-Barreiras ( 40 a $150 \mathrm{~m}$ ) no se puede asociar con cualquier aumento del nivel del mar conocido, posiblemente, la que aparece que procesos neotectónicos han promovido la elevación.
\end{abstract}

Palabras clave: Altiplanicies costeros; Datación; Cuaternario; Sedimentos arenosos.

(*) Doctoral student of Federal University of Viçosa (Universidade Federal de Viçosa) - Avenue Peter Henry Rolfs, s/n, Campus Universitário, CEP 36570-900, Viçosa (MG), Brazil. Tel: (+55 31)3899-1047 - cristiano.souza@ufv.br.

(**) Prof. Dr. of Federal University of Viçosa (Universidade Federal de Viçosa) - Avenue Peter Henry Rolfs, s/n, Campus Universitário, CEP 36570-900, Viçosa (MG), Brazil. Tel: (+55 31) 3899-1047 - liovandomc@yahoo.com.br

(***) Prof. Dr. of State University of Santa Cruz (Universidade Estadual de santa Cruz) - Rodovia Jorge Amado, km 16, CEP 45662-900. Ilhéus (BA), Brazil. Tel (+55 73) 3680-5112 - amoreau@uesc.br;

(****) Prof. Dr. of State University of Santa Cruz (Universidade Estadual de santa Cruz) - Rodovia Jorge Amado, km 16, Bairro Salobrinho CEP 45662-900. Ilhéus (BA), Brazil. Tel (+55 73) 3680-5112 - rlgomes@uesc.br 
SOUZA, C. M. P.; COSTA, L. M.; MOREAU, A. M. S. S.; GOMES, R. L.

\section{INTRODUCTION}

The Barreiras Formation consists of coastal terrigenous sediments of continental origin (BIGARELLA, 1975; VILAS BOAS; SAMPAIO e PEREIRA, 2001) with the influence of marine processes in their formation (Arai, 2006; Garcia and Rossetti, 2009; Rossetti; Bezerra and Dominguez, 2013). They are deposited along the Brazilian coast from Rio de Janeiro to Amapá, and form flattened and elevated surfaces along the coast, called coastal tablelands. Despite the wide territorial coverage, many materials associated to the barrier formation are still not studied very much (Arai, 2006).

In some parts of Brazil, associated with sediments of Barreiras Formation, there are this upper sedimentary unit is referenced in some studies in Brazil as Post-Barreiras sediments (ROSSETTI; TRUCKENBRODT and GARCIA, 1989; ROSSETTI; GOES and SOUZA, 2001; TATUMI et al., 2008; GANDINI et al., 2014). The term 'Post-Barreiras' is generically used to refer to overlapping sediments to coastal tablelands of Barreiras Formations. They consist of a transitional geologic unit in a discordant manner of the Barreiras Formation, and are sometimes characterized as sediment conglomerates with interbedded sand and clay (ROSSETTI et al., 1989; ROSSETTI et al, 2011a; ROSSETTI et al, 2013), or mostly sand (COHEN et al, 2008; TATUMI et al, 2008).

The Post-Barreiras sediments are found only in some areas of the coast of Brazil (ROSSETTI et al., 1989; TATUMI et al, 2008; ROSSETTI and GÓES 2009; ROSSETTI et al, 2013), they are recorded in elevated areas and do not consist of the sedimentary unit of the coastal plain from the Quaternary period which is common along the Brazilian coastline. Studies indicate that the Post-Barreiras sedimentary pile can be tens of meters high, and the altimetric quota of the current location may be related to neotectonic processes subsequent to the deposition (ROSSETTI et al, 2013; GANDINI et al, 2014).

Although there is some pioneering work from the 80s focusing on Post-Barreiras sediments, with some quoted in this work, however, some issues related to sediments have not been sufficiently studied. There is no consensus as to the origin and depositional processes. According to Rossetti et al. (2011a) the prevalence of coarse-grained sand and gravel are compatible with highly energetic coastal environments, which indicate marine activity, on the other hand, the presence of fine sand at high altitudes also suggests wind contribution to the formation of Post-Barreiras sediments.

The lack of consensus regarding the origin and time of sand deposits according to Tatumi et al. (2008) is due to the fact that for a long time these coverages have been a result of weathering of sediments from the Barreiras Formation. Furthermore, sandy material is heavily weathered and it is difficult to obtain reliable radiogenic dating. However, the optically stimulated luminescence method is the most suitable (SALLUN et al., 2007; TATUMI et al., 2008).

The objective of this paper is to analyze sedimentological parameters and dating of Post-Barreiras sediments infer possible transport mechanisms also based on morphological characteristics of sand grains.

\section{GEOLOGICAL AND GEOMORPHOLOGICAL FRAMEWORK}

The study area is located between the coordinates $-14^{\circ} 41^{\prime}$ and $-15^{\circ} 11^{\prime}$ south latitude and from $-39^{\circ} 55^{\prime}$ to $-38^{\circ} 99^{\prime}$ longitude W.Gr (Figure 1). The area includes the coast of Ilheus located in southern Bahia, Brazil. The coastline is positioned at the low latitude of the equator, in the field of the arboreal Atlantic Forest area presenting a tropical climate with high temperatures and rainfall, influenced by the proximity of the sea.

The coastline of the city of Ilhéus presents Barreiras Formation sediments that form the geomorphological unit of costal tablelands (Bigarella, 1975). Deposited on tablelands, there is a sporadic presence of white sand; this upper sedimentary unit is referenced in some studies in Brazil as Post-Barreiras sediments (ROSSETTI; TRUCKENBRODT and GARCIA, 1989; ROSSETTI; GOES and SOUZA, 2001; TATUMI et al, 2008; GANDINI et al, 2014). 


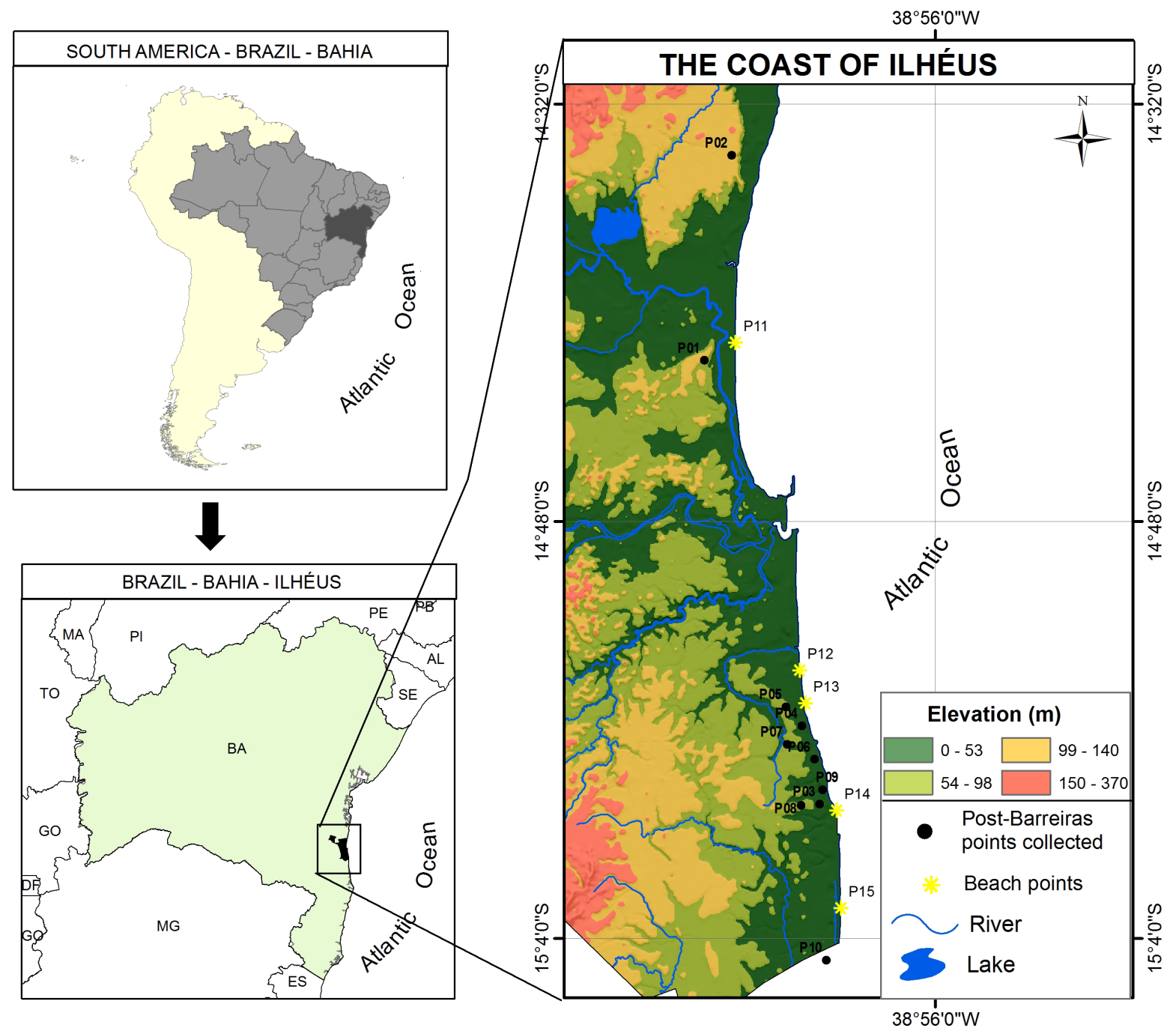

Figure 1 - Location map of the study area

The coast of Ilhéus shows the crystalline basement rocks, which together comprise of the complex Itabuna Intrusive suite and complex Ilhéus with an early Proterozoic to Archean age (ARCHANGEL; BARBOSA and OLIVEIRA, 1992), consisting of rocks such as granite, gneiss and diabase intrusions, alkaline nefelinitos, phonolites and basic subalkalines. The intrusions are observed mainly near the coast. These rocks are more common in the northern part between $14^{\circ} 48^{\prime}$ and $14^{\circ} 32^{\prime}$ parallels. These rocks form the geomorphological unit of massive ancient formations. Geomorphological formations of the study area are shown in Figure 2 and the main geological structures are presented in the stratigraphic outline of the occurrence areas of Post-Barreiras sediments (Figure 3).

In the southern area of the city (below parallel $14^{\circ} 48^{\prime}$ ), the sediments from the Barreiras Formation, overlying the crystalline basement, only arise in the westbound sector. Sediments from the Barreiras Formation show a sandy or sandy-clayey material, and occasionally have concretions of iron oxides that form ferruginous shells.

Sediments from the Barreiras Formation make up the geomorphological unit of coastal tablelands, which were subdivided on the map (Figure 2) as slightly dissected and dissected, both having no contact with the sea. In Ilhéus, they are made up of paleo-cliffs, which are records of changes in sea levels during the Quaternary period which also led to the formation of coastal tablelands mainly 


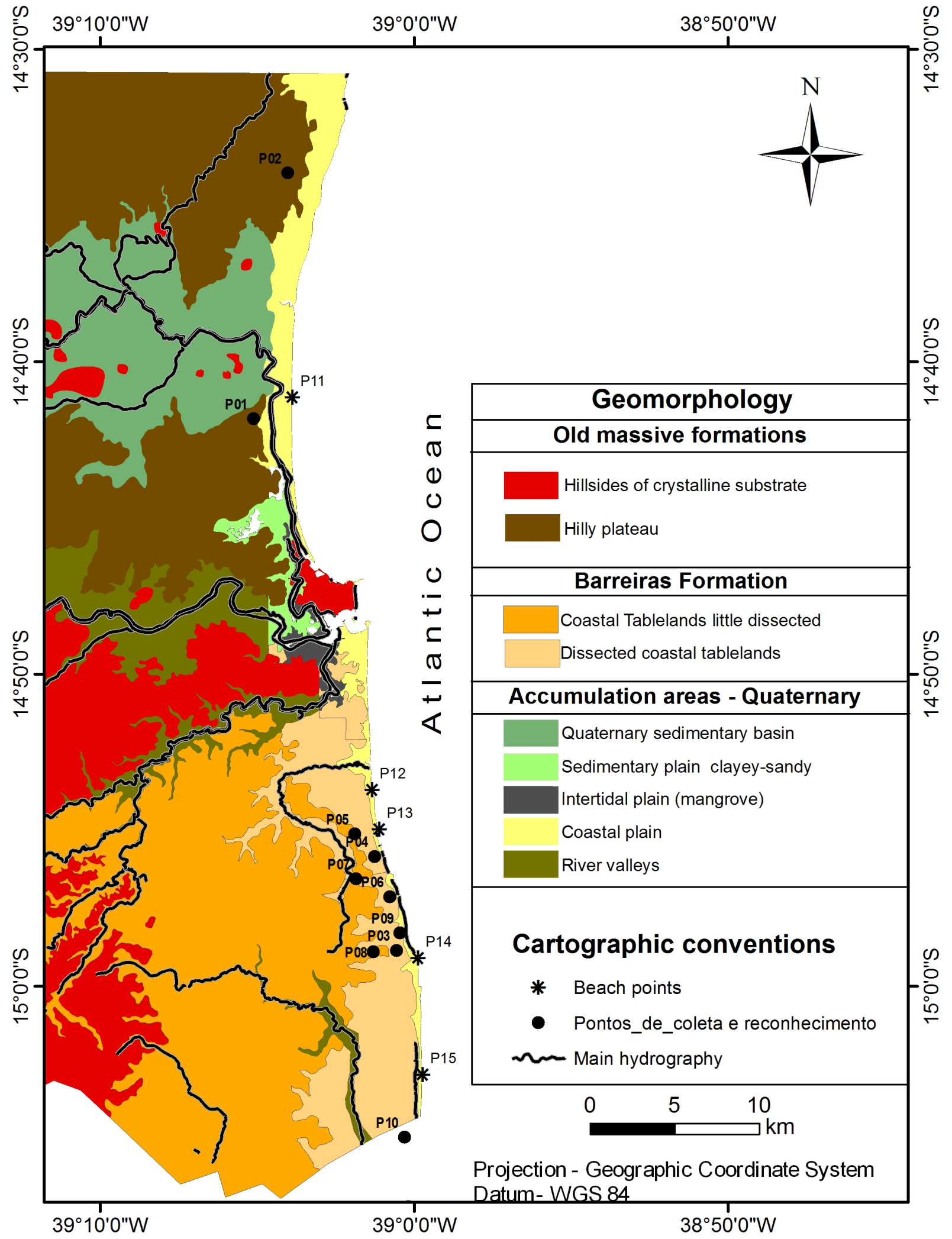

Figure 2 - Geomorphological Map of the Coast of Ilhéus. 


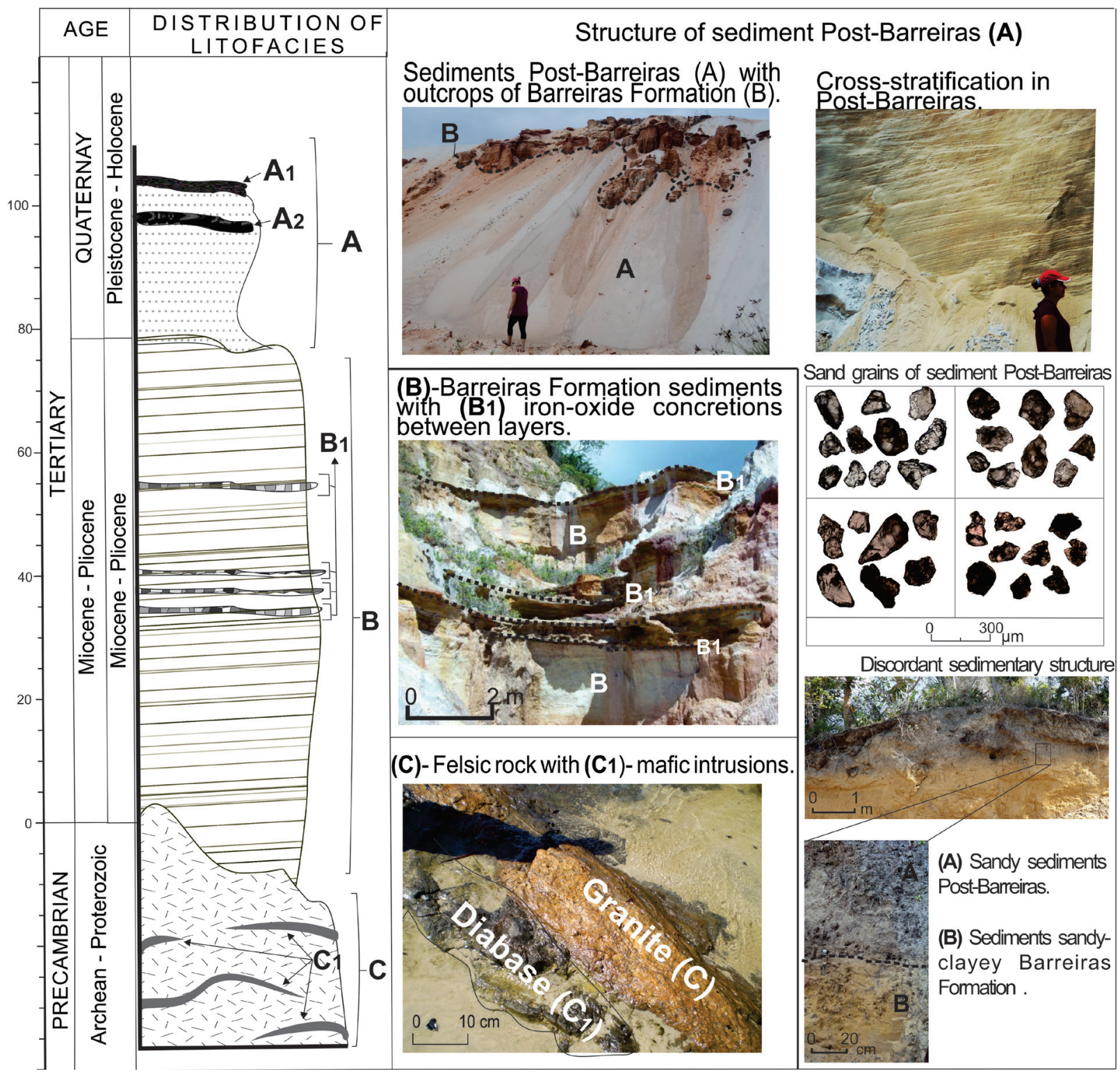

Figure 3 - Standard stratigraphic occurrence areas of Post-Barreiras.

consisting of sandy sediments, which were generated in the last marine regression, associated with successive sediment accretion (MARTIN and SUGUIO, 1992; MARTIN; SUGUIO and FLEXOR, 1993).

In the upper portion of the coastal tablelands there is presence of sandy sediments distributed sporadically which are Post-Barreiras with grain size variations, in some cases with cross-stratification, and can still display cemented and hardened structures formed by illuviation of organic compounds that are denominated as ortstein.

Other geomorphological domains were found in the study area, such as sandy-clayey sedimentary plains formed mainly during the Holocene epoch; shallow river valleys formed in areas where rivers had larger beds; and intertidal plains which are accumulation areas of typical mangrove sediments.

In a geological and geomorphological context of the region, Post-Barreiras sediments are verified occasionally as overlapping the sediments from the Barreiras Formation, mainly in sub-unit 
geomorphological coastal tablelands, which are located closer to the shoreline. An occurrence of Post- Barreiras sediments has been verified up to $5 \mathrm{~km}$ away from the coastline (Figure 4).

In the northern area of Ilhéus, the Post-Barreiras sediments are situated at altitudes up to 150 $\mathrm{m}$. The sediments are located in elevated blocks, as recorded in the topographic profile in Figure 5A e B This region, in accordance with Pereira (2001) It has been submitted by neotectonic processes. Evidence of neotectonic processes are reported in some studies in the southern area of Bahia (NETTO e SANCHES, 1991; PEREIRA, 2001; ALMEIDA, 2006; CORREA-GOMES et al., 2007). In region, the most striking evidence of neotectonic processes are changes in drainage channels, especially the Almada river, which undergoes a shift of nearly $90^{\circ}$ southward and follows sinuously along the Aritagua fault plane and the coastline, until the mouth (NETTO and SANCHES, 1991) (Figure 5A). Moreover, in some of the sites a break in the continuity of spodic horizons in Spodosol profiles is observed, indicating rupture processes (Figure 5C).

\section{METHODOLOGY}

\section{Methodological Procedures}

Fieldwork was conducted, on which were selected representative points of the areas of occurrence of Post-Barreiras sediments, as a criterion point collected should represent a landscape pattern which was inserted. Beach sediment samples were collected in areas outside the surf influence. In total, fifteen samples were collected, in which ten of them were the Post-Barreiras material and five from beach sand. Procedures for separation of silt, clay and sand fractions were performed. The samples were treated with $\mathrm{H} 2 \mathrm{O} 2$ for oxidizing of possible organic materials, after using the chemical dispersant $\mathrm{NaOH} 0.1 \mathrm{~mol} \mathrm{~L}-1$. The sand fraction was subjected to mechanical sieving with an interval between screens of $1 / 2$ phi $[\phi]$ from Wentworth's scale (1922).

The size of the grains in each sieve were used for the calculation of sediment parameters, according to the method defined by (FOLK and WARD, 1957) and were logarithmically transformed in $\left.{ }^{\text {phi }[} \phi\right]$ values using the expression ${ }^{\phi=-\log _{2} \mathrm{~d}}$, where $\mathrm{d}$ is the grain diameter in millimeters (UDDEN, 1898; WENTWORTH, 1922). The sedimentological parameters calculated were the median, mean, selection [standard deviation], skewness and kurtosis. Equations defined by Folk and Ward (1957) were worked into the SYSGRAN statistical program (CAMPBELL, 2006). The samples were only analyzed in its sandy fractions, since the silt clay fractions can largely be traced due to weathering, and fine materials can falsify the depositional grain size composition.

Photographs were taken using an optical microscope for medium sand fractions, and calculated the degree of sphericity of the grains [degree of rounding]. The software used for this calculation was the UTHSCSA Image Tool (WILCOX et al., 2002). A visual analysis of the grains was also included and compared to Krumbein's chart (1941).

Three samples were collected for dating. The points were selected so that represent the pattern of occurrence sediments Post-Barreiras, mainly slope and elevation. The dating method used was the Optically Stimulated Luminescence [OSL]. Samples were collected with plastic tubes PVC 40-cm-long and $5 \mathrm{~cm}$ in diameter. The tubes, protected in both sides with caps, had no transparency in order to avoid renewed bleaching by sunlight. Samples were collected horizontally in homogeneous layers of sediment, which were previously cleaned. the collection procedures were based on Aitken (1985); Olley; Caitcheon \& Roberts (1999) and Sallun et al. (2007). The analyses were performed at the Dating, Commerce and Provision of Services Laboratory Ltda, located in São Paulo, SP - Brazil. 


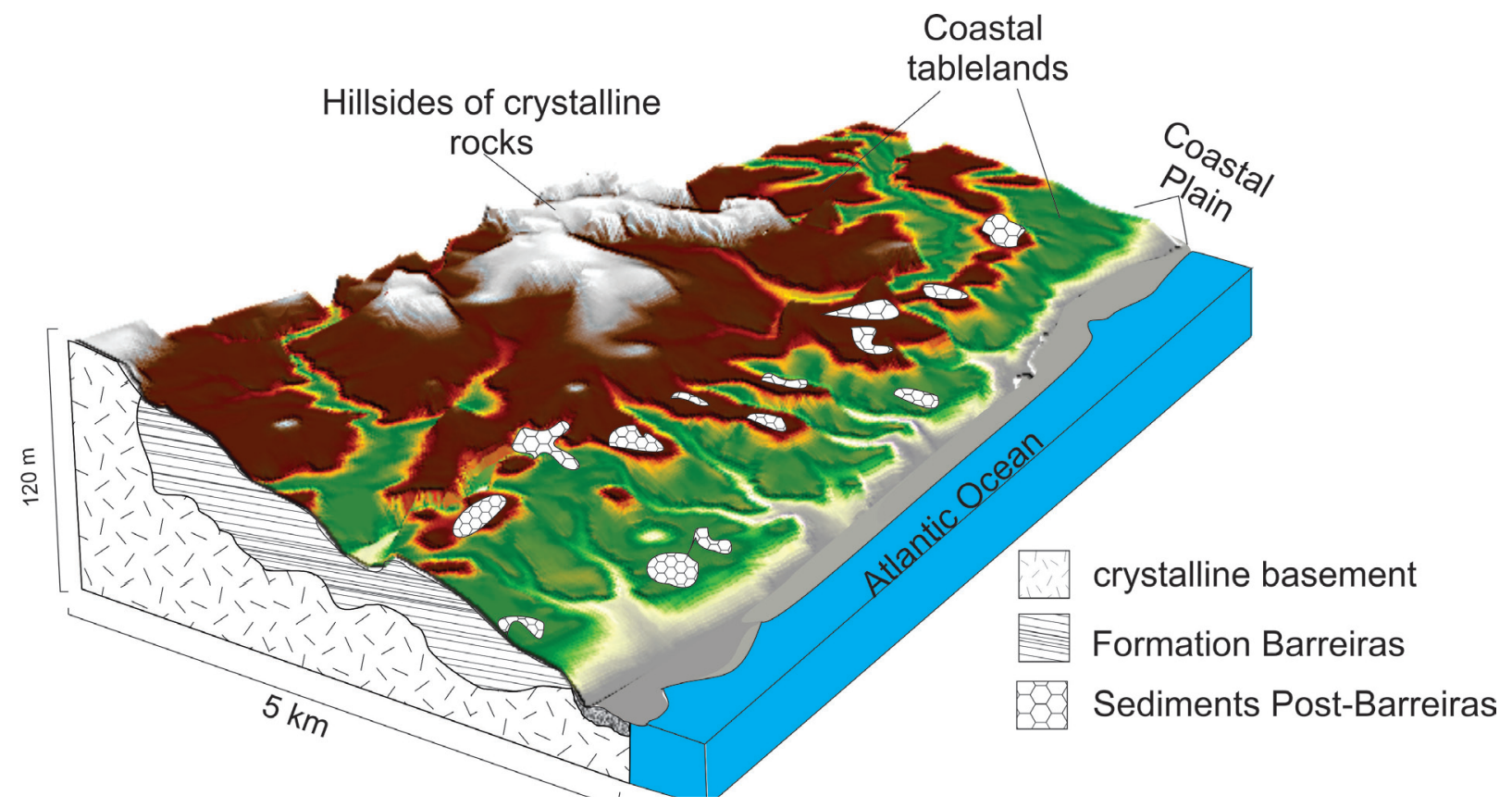

Figure 4 - Block diagram of the raised occurrence areas of Post-Barreiras sediments in the southern area of Ilhéus.

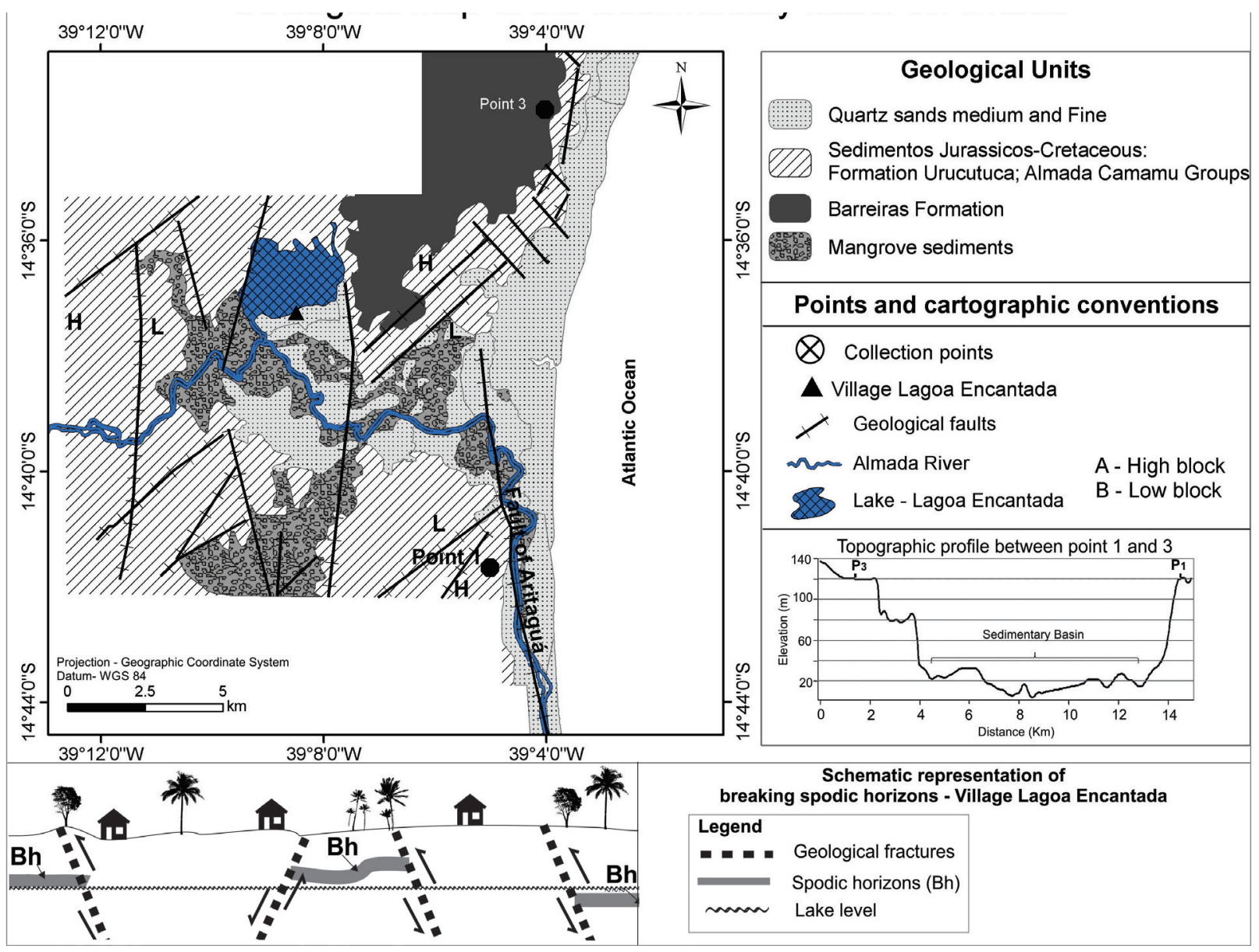

Figure 5 - (A) - Geological Map of the Almada Basin, (B) - Topographic Profile representative to the location of the Post-Barreiras sediments from collection points 1 and 2. (C) - Representative scheme of the discontinuity of spodic horizons (ortstein) due to activity of neotectonic processes. 


\section{RESULTS AND DISCUSSION}

\section{ANALYSIS OF POST-BARREIRAS SEDIMENTS}

Post-Barreiras sediments are essentially sandy, with sand content that reaches 98 dag kg-1, the average rating of the sand grains is medium to fine sand. From images obtained by optical microscope, the grains were classified by comparative analysis with the table (scale) defined by powers (1953), that defines the degree of rounding of the grains. Thus, the grains Post-Barreiras were classified as angular and subangular. Besides a visual analysis, the results obtained from the degree of roundness, used by the UTHSCSA Image Tool Software (WILCOX et al., 2002), showed values ranging from 0.196 to 0.136 , and the average of all the grains was 0.163 , framing them in the very angular class and the angular class.

In general, the grain of the Post-Barreiras sediments showed low roundness, what emerges are two possibilities: The morphological characteristics may indicate that the sediments were transported in an aqueous environment, because the grains which are transported by wind processes are more rounded due to the low viscosity of air, which implies a collision between the grains with greater force (PAISANI, 2005); another possibility is due to short distance from occurrence of sediment in relation the coastline (maximum $5 \mathrm{~km}$ ), on which the carriage in short distance, has kept the low degree of rounding of grains

Table 1 - Sedimentological parameters calculated [phi scale], with a verbal rating

\begin{tabular}{|c|c|c|c|c|}
\hline Samples & $\operatorname{Mean} M_{z}$ & Sorting $\sigma_{I}$ & Skewness $S k_{i}$ & Kurtosis $K_{g}$ \\
\hline & \multicolumn{4}{|c|}{ Post-Barreiras Sediments } \\
\hline P1 & $-0.0188 \mathrm{VCS}$ & 0.8351 ModS & $0.576 \mathrm{VP}$ & $2.054 \mathrm{VL}$ \\
\hline $\mathrm{P} 2$ & $0.5097 \mathrm{CS}$ & 1.197 PS & $0.5411 \mathrm{VP}$ & $0.7669 \mathrm{Pl}$ \\
\hline $\mathrm{P} 3$ & $1.777 \mathrm{MS}$ & 0.8859 ModS & $-0.2749 \mathrm{~N}$ & $1.238 \mathrm{~L}$ \\
\hline $\mathrm{P} 4$ & $1.417 \mathrm{MS}$ & $1.061 \mathrm{PS}$ & $-0.153 \mathrm{~N}$ & $1.213 \mathrm{~L}$ \\
\hline P5 & $0.9795 \mathrm{CS}$ & 1.132 PS & $-0.02331 \mathrm{AS}$ & $0.7215 \mathrm{Pl}$ \\
\hline P6 & $0.1888 \mathrm{CS}$ & 0.8928 ModS & $0.4775 \mathrm{VP}$ & $0.7925 \mathrm{Pl}$ \\
\hline P7 & $1.2 \mathrm{MS}$ & 1.148 PS & $-0.1283 \mathrm{~N}$ & $0.8662 \mathrm{Pl}$ \\
\hline P8 & $0.105 \mathrm{CS}$ & 1.005 PS & $0.7313 \mathrm{VP}$ & $0.6318 \mathrm{VPl}$ \\
\hline P9 & $1.173 \mathrm{MS}$ & $1.128 \mathrm{PS}$ & $-0.1141 \mathrm{~N}$ & $0.8046 \mathrm{Pl}$ \\
\hline \multirow[t]{2}{*}{ P10 } & $1.169 \mathrm{MS}$ & $1.187 \mathrm{PS}$ & $-0.07957 \mathrm{AS}$ & $0.7751 \mathrm{Pl}$ \\
\hline & \multicolumn{4}{|c|}{ Sediments of the coastline } \\
\hline P11 & $2.243 \mathrm{FS}$ & $0.3193 \mathrm{VWS}$ & -0.02589 AS & $1.68 \mathrm{VL}$ \\
\hline $\mathrm{P} 12$ & $2.235 \mathrm{FS}$ & $0.3414 \mathrm{VWS}$ & $-0.09287 \mathrm{AS}$ & $1.836 \mathrm{VL}$ \\
\hline $\mathrm{P} 13$ & $2.244 \mathrm{FS}$ & $0.3286 \mathrm{VWS}$ & $-0.02637 \mathrm{AS}$ & $1.746 \mathrm{VL}$ \\
\hline $\mathrm{P} 14$ & $2.239 \mathrm{FS}$ & 0.3229 VWS & -0.03197 AS & $1.712 \mathrm{VL}$ \\
\hline P15 & $2.247 \mathrm{FS}$ & 0.3205 VWS & $-0.01344 \mathrm{AS}$ & $1.668 \mathrm{VL}$ \\
\hline
\end{tabular}

(CS - Coarse Sand, MS - Medium Sand, FS - Fine Sand. / ModS - Moderately Sorted, PS- Poorly Sorted, VWS - Very Well Sorted. / VP - Very Positive, N - Negative, AS - Approximately Symmetric. / VL - Very Leptokurtic, L- Leptokurtic, PL -Platikurtic, VPl - Very Platikurtic)

The points collected from the Post-Barreiras sediments showed, on average, a very thick diameter of sand, while beach sediments were only classified as fine sand. Overall, these results indicate that deposition of Post-Barreiras sediments was in a higher energy environment in comparison to the dynamics of the current sand deposition in the post-beach coastal plains. 
The degree of selection is a reflection of the predominance of a dynamic process of deposition. More heterogeneous sediments with depositional marine and wind association tend to be poorly selected. Thus, the Post-Barreiras sediments have been classified as moderately and poorly selected, which may indicate that the deposition was a consequence of the action of two deposition mechanisms. However, due to the wide distribution of Post-Barreiras sediments, associated to the lack of paleontological evidence of drainage channels, which extinguishes the possibility of fluvial contribution to sedimentary deposition, except for P1.

P1 located at an altitude of $120 \mathrm{~m}$ showed in its composition the greater presence of coarse sand fraction and with occurrence of a range of quartz pebbles, joins the fact that the altitude of the site implies a barrier for wind sedimentation. However, in this site sediments may be related to fluvial deposits of ancient rivers, that have changed its course due to neotectonics. Although there are no conclusive studies on the neotectonic in the region, evidence presented by Pereira (2001) previously reported this study, are factors that should be taken into account.

The sediments from the beach line were classified as very well selected. Studies by Friedman (1961) classified the coastal sediments as poorly sorted, resulting from the action of spreading and wind action processes. In the collected points there is no direct influence on the rising sea level and such sediments are very well sorted due to wind action.

The data of skewness and kurtosis indicate that beach sands exhibit negative skewness due to the greater presence of coarse sand, while sand from rivers and dunes have positive skewness, due to the predominance of the transport agent for unidirectional flow. The Post-Barreiras sediments showed negative asymmetry in $40 \%$ of the samples and showed very positive in another $40 \%$, while $20 \%$ were classified as approximately symmetrical. Therefore, there is no standard in the asymmetrical parameter. This may be related, in some cases, with recent wind reworkings for some of the collection points.

For point 6 collected at a depth of 12 meters, where there should not be any influence by current aeolian processes, therefore, it should better reflect past conditions of deposition, the asymmetry was classified as very positive, with a moderate selection degree of typical patterns of wind environments but the predominant fraction is coarse sand, a fraction that is not easily transported by wind processes, which in turn indicates that the carrier may have been strongly energetic, i.e. sea contribution to the formation.

The asymmetry of the sand from the shoreline, all classified as approximately symmetrical, possibly due to little influence of rising tides and loaded amounts of fine particles become fixed due to the vegetation, which results in leptokurtic kurtosis patterns that according to studies by Martins (1965) and Van Der Wal (2000) are typical of shoreline environments.

Kurtosis measures the degree of sharpness of peaks in frequency distribution curves. Samples of Post-Barreiras sediments (70\% of the sample) were classified as Platykurtic, which show a spreading of thinner and thicker sediment tails, and indicate a mixture of different sub-populations for the formation of sediments, which may set up the joint action of wind and marine processes.

In a general context, the analysis of sediments can be attributed to wind activity in the deposition of Post-Barreiras sediments, but some sedimentological parameters associated with a predominance of coarse sand and sediment characteristics of the grain shapes are a set of results that lead us to believe in marine deposition. This argument is in line with proposed indications by Gandini et al. (2014).

\section{DATING OF THE SAMPLES}

The profiles dated were point's 1, 2 and 5 (Table 2). They are far away from the coast up to $2.8 \mathrm{~km}$, collected at an average depth of $1.4 \mathrm{~m}$. 
SOUZA, C. M. P.; COSTA, L. M.; MOREAU, A. M. S. S.; GOMES, R. L.

Table 2 - Ages of Post-Barreiras sediments obtained by optically stimulated luminescence (OSL) dating.

\begin{tabular}{c|c|c|c|c|c|c|c}
\hline Points & $\begin{array}{c}\text { Depth } \\
\text { (m) }\end{array}$ & $\begin{array}{c}\text { Th } \\
(\mathbf{p p m})\end{array}$ & $\mathbf{U}(\mathbf{p p m})$ & $\mathbf{K}(\%)$ & $\begin{array}{c}\text { Annual dose rate }(\mu \mathrm{Gy} / \\
\text { year) }\end{array}$ & $\begin{array}{c}\text { Accumulated } \\
\text { dose(Gy) }\end{array}$ & Age \\
\hline 1 & 1,2 & 2.4 & 1.5 & 0.4 & $1.135 \pm 80$ & 96.6 & $85.4 \pm 10.4$ \\
\hline 3 & 1,3 & 3.1 & 1.0 & 0.5 & $1.220 \pm 150$ & 8.5 & $7.0 \pm 10.4$ \\
\hline 5 & 1,5 & 2.2 & 1.2 & 0.4 & $1.050 \pm 150$ & 19.6 & $18.8 \pm 3.0$ \\
\hline
\end{tabular}

Point 1 located near the area of the sedimentary basin Almada, in an altitude of $120 \mathrm{~m}$, showed an age of $85,4 \mathrm{ka}( \pm 10,4)$, this was the oldest age among the dated points. The collection site features shingle tracks in certain sections. The sandy layer (Post-Barreiras) of the collection site has little thickness, not exceeding $1.7 \mathrm{~m}$. Thus, the origin of this material may be related to the old river bed, which had its course changed because of neotectonic processes that occurred in the area (Pereira, 2001). The main evidence is arrangement pebbly layers in contact between sandy and clay deposits (underlying), which are disposed in line (stones line), indicating unidirectional energy flow during deposition.

Point 2 was collected further north in relation to point 1, both located in elevated areas and are separated by a lowered sedimentary unit (Almada basin). This point showed ages of 6,9 ka ( \pm $1,2)$, the sand at this site occurs more continuously in large quantities, in a very similar way to the Post-Barreiras materials from the southern sector. However, even though it is in the area directly influenced by neotectonic processes, the large amount of sedimentary material and its spatial distribution does not support the possibility of a river source, since in the region there is no geological evidence of torrential river activity to promote large deposits.

Point 5, located in the southern sector of Ilhéus, was the collection site with a lower altitude $(80 \mathrm{~m})$, and $2.17 \mathrm{~km}$ away from the coast line. The sediments are on the geomorphological unit of the dissected coastal tablelands. The registered age of point 5 was $18,8 \mathrm{ka}( \pm 3,0)$. The area has a great distribution of sand, which rules out the possibility of fluvial processes since the region also has no rivers to promote large sand supply. The ages for the points are from the geological period of the late Pleistocene to Holocene epoch, and fall under the dating carried out by Tatumi et al. (2008), Rossetti et al. (2011b), and Gandini et al. (2014).

Assuming that Post-Barreiras sediments were deposited in high-energy environment, presumably marine. However, the altitude of the occurrence of sediments creates a conflict, since the maximum elevation of sea level was $5 \mathrm{~m}$ during the age periods obtained (Martin et al., 1993; Martin; Dominguez and Bittencourt, 2003; Suguio et al., 2013). The counterintuitivity between the ages obtained and the record of the rising sea level can bring an a priori to two explanations. The first refers to ages obtained in which the values may have been influenced by subsequent wind reworkings to deposition and even limitations of the dating method OSL, however dating of Post-Barreiras sediments in other regions of Brazil showed the same age ranges (TATUMI et al., 2008; ROSSETTI et al., 2011B; GANDINI et al., 2014). The second explanation, supporting the hypothesis raised by Gandini et al. (2014) in the region of Pernambuco refers to neotectonic processes.

Several studies have reported tectonic reactivations having occurred in the Cenozoic era, especially in northeastern Brazil (BEZERRA, 2000; PEULVAST et al., 2006; ROSSETTI et al., 2012). When highlighting the region of Ilhéus, the sedimentary basin of Almada, with a Mesozoic age, configures an important indicator of these neotectonic processes, in which faults were reactivated, evidenced as example, by a geomorphic feature, changes in riverbeds, and unevenness of spodic horizons (Pereira, 2001).

Although the results indicate marine contribution to the formation of Post- Barreiras sediments, one should not dismiss wind holdings in deposition, especially during drier periods, however the 
altitudinal position of sediments would even complicate wind activity in sediment transport. Thus, regardless of the deposition mechanism, the assumption arises that the region was in a lower elevation than it currently is.

\section{FINAL CONSIDERATIONS}

The analysis of the geomorphology of the region associated with areas of Post-Barreiras sediments allowed us to affirm that the sediments are restricted to the coast to $5 \mathrm{~km}$ at altitudes up to $120 \mathrm{~m}$, coming from the coast. The morphological characteristics of the sand grains and some sediment parameters presented standards for marine sediment deposition. However, the beach sediments were characteristic of aeolian sediments, justified since the collection site was in the area beyond the line of tidal action and sets up a frontal dune deposit. This is assuming that the deposits are caused by marine processes.

The ages obtained for the Post-Barreiras sediments were from the late Pleistocene to Holocene epoch. Assuming that the ages are correct and that the sediments were originated by marine processes, and knowing that there were no changes in the sea level to the current position of the sediments, it can be inferred that the deposition of sediments took place in times in which the relief was in lower altitudes than current ones.

Thus, the Post-Barreiras sediments can be configured as evidence of rising sea levels occurring during the Quaternary period, and from neotectonic activity. However, this last argument still needs elucidation and identification of geological records to a broader area along the southern coast of Bahia.

\section{BIBLIOGRAPHY REFERENCE}

AITKEN, M. J. Thermoluminescence dating. London: Academic Press, 1985. 359 p.

ALMEIDA, Â. B. História de preenchimento do vale inciso da lagoa encantada - Ilhéus-BA, durante o Quaternário. 2006. 130 f, Dissertação (Curso de Pós-Graduação em Geologia) - Universidade Federal da Bahia, Salvador, BA, 2006.

ARAI, M. A grande elevação eustática do mioceno e sua influência na origem do grupo barreiras. Geologia USP. Série Científica. v. 6, p. 1-6, 2006.

ARCANJO, J. B.; BARBOSA, J. S.; OLIVEIRA, J. E. Caracterização petrografica e metamórfica dos granulitos do Arqueano/Protezóico Inferior da região de Itabuna-Bahia. Brazilian Journal of Geology. v. 22, n. 2, p. 47-55, 1992.

BEZERRA, F. H. R. Neotectonic movements in northeastern Brazil: implications for a preliminary seismic-hazard assessment. Brazilian Journal of Geology. v. 30, n. 3, 2000.

BIGARELLA, J. J. The Barreiras group in northeastern Brazil. Anais da Academia Brasileira de Ciências. v. 47, p. 365-393, 1975.

CAMARGO, M. D. SysGran: um sistema de código aberto para análises granulométricas do sedimento. Revista Brasileira de Geociencias. v. 36, n. 2, p. 371-378, 2006.

COHEN, M. C. L.; LARA, R. J.; SMITH, C. B.; ANGÉLICA, R. S.; DIAS, B. S.; PEQUENO, T. Wetland dynamics of Marajó Island, northern Brazil, during the last 1000 years. CATENA. v. 76, n. 1, p. 70-77, 2008. CORREAA-GOMES, L. C.; DOMINGUEZ, J. M. L.; BARBOSA, J. S. F.; DA SILVA, I. C.; PINTO, M. V. Relações entre orógenos, zonas de cisalhamento, quebra continental e deformações 3-d. a história tectônica da Bacia Sedimentar de Almada, Bahia. Brazilian Journal of Geology. v. 35, n. 4, p. 105-115, 2007.

FOLK, R. L.; WARD, W. C. Brazos River bar [Texas]; a study in the significance of grain size parameters. Journal of Sedimentary Research. v. 27, n. 1, p. 3-26, 1957.

FRIEDMAN, G. M. Distinction between dune, beach, and river sands from their textural characteristics. Journal of Sedimentary Research. v. 31, n. 4, p. 514, 1961. 
SOUZA, C. M. P.; COSTA, L. M.; MOREAU, A. M. S. S.; GOMES, R. L.

GANDINI, R.; ROSSETTI, D. D. F.; NETTO, R. G.; BEZERRA, F. H. R.; GÓES, A. M. Neotectonic evolution of the Brazilian northeastern continental margin based on sedimentary facies and ichnology. Quaternary Research. v. 82, n. 2, p. 462-472, 9// 2014.

KRUMBEIN, W. C. Measurement and geological significance of shape and roundness of sedimentary particles. Journal of Sedimentary Research. v. 11, n. 2, 1941.

MARTIN, L.; DOMINGUEZ, J. M.; BITTENCOURT, A. C. Fluctuating Holocene sea levels in Eastern and Southeastern Brazil: evidence from multiple fossil and geometric indicators. Journal of Coastal Research. p. 101-124, 2003.

MARTIN, L.; SUGUIO, K. Variation of coastal dynamics during the last 7000 years recorded in beach-ridge plains associated with river mouths: example from the central Brazilian coast. Palaeogeography, Palaeoclimatology, Palaeoecology. v. 99, n. 1-2, p. 119-140, 1992.

MARTIN, L.; SUGUIO, K.; FLEXOR, J. As flutuações de nível do mar durante o quaternário superior e a evolução geológica de" deltas" brasileiros. Boletim IG-USP. Publicação Especial. n. 15, p. 01-186, 1993.

MARTINS, L. R. Significance of skewness and kurtosis in environmental interpretation. Journal of Sedimentary Research. v. 35, n. 3, p. 768-770, 1965.

NETTO, A. S.; SANCHES, C. P. Roteiro Geológico da Bacia de Almada, Bahia. Revista Brasileira de Geociencias. v. 21, n. 2, p. 186-198, 1991.

OLLEY, J. M.; CAITCHEON, G. G.; ROBERTS, R. G. The origin of dose distributions in fluvial sediments, and the prospect of dating single grains from fluvial deposits using optically stimulated luminescence. Radiation Measurements. v. 30, n. 2, p. 207-217, 4// 1999.

PAISANI, J. C. Análise morfométrica e de textura superficial de grãos utilizada na identificação de litofácies eólica e de dissipação em rampa arenosa/dissipação: o caso da Praia Mole (Ilha de Santa Catarina). Geosul. v. 20, n. 39, p. 105-118, 2005.

PEREIRA, A. D. C. Lagoa encantada testemunho de uma baía quaternária Ilhéus - Bahia Brasil. 2001. 166 p. Doutorado em Ciências da Terra. Departamento de Ciências da Terra, Universidade do Minho, Braga-Portugal.

PEULVAST, J.-P.; SALES, V. C.; BEZERRA, F. H. R.; BETARD, F. Landforms and Neotectonics in the Equatorial Passive Margin of Brazil. Geodinamica Acta. v. 19, n. 1, p. 51-71, 2006/02/01 2006.

POWERS, M. C. A new roundness scale for sedimentary particles. Journal of Sedimentary Research. v. 23, n. 2, p. 117-119, 1953.

ROSS, J. L. S. Geomorfologia: ambiente e planejamento. São Paulo: Contexto, 2003. 85 p.

ROSSETTI, D. F.; BEZERRA, F. H.; GOES, A. M.; VALERIANO, M. M.; ANDRADES-FILHO, C. O.; MITTANI, J. C.; TATUMI, S. H.; BRITO-NEVES, B. B. Late Quaternary sedimentation in the Paraíba Basin, Northeastern Brazil: landform, sea level and tectonics in Eastern South America passive margin. Palaeogeography, Palaeoclimatology, Palaeoecology. v. 300, n. 1, p. 191-204, 2011 b.

ROSSETTI, D. F.; BEZERRA, F. H. R.; DOMINGUEZ, J. M. L. Late Oligocene-Miocene transgressions along the equatorial and eastern margins of Brazil. Earth-Science Reviews. v. 123, n. 0, p. 87-112, 2013.

ROSSETTI, D. F.; BEZERRA, F. H. R.; GÓES, A. M.; NEVES, B. B. B. Sediment deformation in Miocene and post-Miocene strata, Northeastern Brazil: Evidence for paleoseismicity in a passive margin. Sedimentary Geology. v. 235, n. 3-4, p. 172-187, 2011a.

ROSSETTI, D. F.; GÓES, A. M. Marine influence in the Barreiras Formation, State of Alagoas, Northeastern Brazil. Anais da Academia Brasileira de Ciências. v. 81, n. 4, p. 741-755, 2009.

ROSSETTI, D. F.; GÓES, A. M.; SOUZA, L. S. B. Estratigrafia da sucessão sedimentar Pós-Barreiras (Zona Bragantina, Pará) com base em radar de penetração no solo. Revista Brasileira de Geofísica. v. 19, p. 113-130, 2001.

ROSSETTI, D. F.; SOUZA, L. S. B.; PRADO, R.; ELIS, V. R. Neotectonics in the northern equatorial Brazilian margin. Journal of South American Earth Sciences. v. 37, n. 0, p. 175-190, 2012.

ROSSETTI, D. F.; TRUCKENBRODT, W.; GÓES, A. M. Estudo paleoambiental e estratigráfico dos sedimentos barreiras e Pós-Barreiras na Região Bragantina, Nordeste do Pará. Bol. Mus. Para. Emílio Goeldi, sér. Ciências da Terra. p. 25 -74, 1989. 
SALLUN, A. E. M.; SUGUIO, K.; TATUMI, S. H.; YEE, M.; SANTOS, J.; BARRETO, A. M. F. Datação absoluta de depósitos quaternários brasileiros por luminescência. Revista Brasileira de Geociencias. v. 37 , n. 2, p. 402-413, 2007.

SUGUiO, K.; BARRETO, A. M. F.; OLIVEIRA, P. E. D.; BEZERRA, F. H. R.; VILELA, M. C. S. H. Indicators of Holocene sea level changes along the coast of the states of Pernambuco and Paraíba, Brazil. Geologia USP. Série Científica. v. 13, p. 141-152, 2013.

TATUMI, S. H.; SILVA, L. P. D.; PIRES, E. L.; ROSSETTI, D. F.; GÓES, A. M.; MUNITA, C. S. Datação de Sedimentos Pós-Barreiras no norte do Brasil: implicações paleogeográficas. Revista Brasileira de Geociencias. v. 38, n. 3, p. 514-524, 2008.

UDDEN, J. A. The Merchanical Composition of Wind Deposits. Lutheran Augustana book concern, printers, 1898.

VALERIANO, M. D. M.; ROSSETTI, D. D. F. Topographic modeling of Marajó Island with SRTM data. Revista Brasileira de Geomorfologia. v. 9, n. 1, 2010.

VAN DER WAL, D. Grain-size-selective aeolian sand transport on a nourished beach. Journal of Coastal Research. p. 896-908, 2000.

VILAS BOAS, G. S.; SAMPAIO, F. J.; PEREIRA, A. The Barreiras Group in the Northeastern coast of the State of Bahia, Brazil: depositional mechanisms and processes. Anais da Academia Brasileira de Ciências. v. 73, n. 3, p. 417-427, 2001.

WENTWORTH, C. K. A scale of grade and class terms for clastic sediments. The Journal of Geology. p. 377-392, 1922.

WILCOX, C.; DOVE, S.; MCDAVID, W.; GREER, D. UTHSCSA Image Tool. San Antonio, TX: The University of Texas Health Science Center. 2002.

Submitted august 2016

Accepted september 2016 